\title{
Effects of Moringa Oleifera Leaves and Honey Supplementation during Pregnancy on Mothers and Newborns: A Review of the Current Evidence
}

\author{
Veni Hadju ${ }^{1}$, Muhammad Dassir ${ }^{2}$, Andi Sadapotto ${ }^{2}$, Aliyah Putranto ${ }^{3}$, Geoffrey Marks ${ }^{4}$, Andi Imam Arundhana ${ }^{1 *}$ \\ ${ }^{1}$ School of Public Health, Hasanuddin University, Makassar, Indonesia; ${ }^{2}$ School of Forestry, Hasanuddin University, Makassar, \\ Indonesia; ${ }^{3}$ School of Pharmacy, Hasanuddin University, Makassar, Indonesia; ${ }^{4}$ School of Public Health, University of \\ Queensland, Brisbane, Australia
}

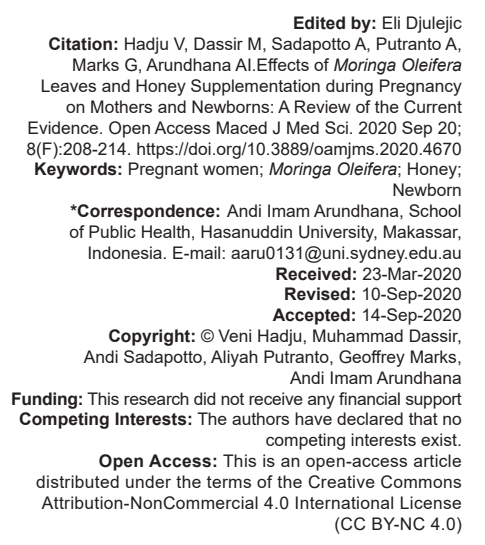

\section{Abstract}

BACKGROUND: Malnutrition in pregnant women has been known to bring effects on the mothers' and infants health. Food or nutrient supplementation is now being used to correct the problems. Moringa Oleifera leaves and honey are the two types of natural supplements used by pregnant women.

AIM: This systematic review aimed to evaluate the potential effects of Moringa, honey, and both compared to ironfolic acid supplements given to pregnant women on the pregnancy outcomes.

METHODS: A systematic review was conducted to evaluate the extent of the benefits of the supplementation of $M$ Oleifera, honey, or both against pregnant women. There were seven studies which are conducted in Indonesia on this topic.

RESULTS: This review shows that M. Oleifera leaves in the form of extract and powder as well as honey could improve maternal weight and hemoglobin, and baby's birth weight. Moreover, both interventions could reduce stress and protect mothers and their babies from negative effects of oxidative stress.

CONCLUSION: Nevertheless, efforts are needed to formulate a recommended dose as adequate supplements for pregnant women.

\section{Introduction}

Malnutrition in pregnant women is still prevalent in developing countries. Pregnant women are not only experiencing macronutrients deficiency but also a variety of micronutrients deficiency in the form of vitamins and minerals [1]. Inadequate food intake and high level of activities are the main contributing factors of malnutrition among pregnant women, particularly those who are from low-economic status [2], [3]. Studies about food intake of pregnant women in poor countries show that pregnant women generally only consume about half of the recommended dietary intake of energy. Low consumption is generally caused by poverty, ignorance or inadequate care to the nutritional needs of pregnant women.

Malnutrition among pregnant women will bring some adverse impact to the fetal growth and development [4]. In addition, lack of vitamins and minerals as well as amino acids and fatty acids are needed adequately to prevent cells damage. This is associated with the incidence of morbidity in pregnant women such as hypertension, pre-eclampsia, and a variety of other disorders [5]. Pregnant women are also particularly vulnerable with the incidence of anemia which is the most common nutritional problems found at this time. This is particularly associated with nutrients including iron, Vitamins $\mathrm{A}, \mathrm{B}$, and $\mathrm{C}$, and a variety of other minerals such as zinc, magnesium, and selenium. The long-term consequences of malnutrition in pregnant women will result in their offspring in the form of low cognitive performance, growth faltering, low productivity, and the incidence of degenerative diseases in adulthood [6].

Supplementary feeding programs in pregnant women have been carried out in many countries. In Indonesia, for example, current supplementary feeding is given in the form of a biscuit rich in protein, fat, and a variety of vitamins and minerals [7]. Multiple micronutrients supplementation containing 14 micronutrients is introduced and has been tested in many countries [8]. A review from thirteen studies has revealed that this led to a decline in short for gestational age and preterm babies, but there is no decrease in the morbidity and mortality rates of mother and infant. 
Moreover, the best solution in obtaining optimal health of pregnant women and their infants is to look for local resources that could be more accessible and easily implemented.

Natural supplementation such as Moringa and honey is the alternatives that have received attention in the past two decades. These foods are easy to obtain, and they are available abundantly in many low-middle income countries. Moringa plant, which is also known as a Miracle Tree, is a plant that contains many different nutrients and phytochemicals that are higher compared to any other plants. This plant is probably beneficial for pregnant women who commonly experience with micronutrient deficiencies as Moringa leaves contain high vitamins and minerals. Moringa also has iron and vitamin other trace elements that are essential for pregnancy. In addition, it contains numerous phytochemicals substances, which are needed for preventing free radicals and treating noncommunicable diseases. Research on the nutritional content and benefits of the benefit of Moringa leaves has been widely performed in various countries and shown that this plant contains many antioxidant constituents [9], [10].

Another natural food containing various nutrient content and high phytochemical is honey [11], [12]. Honey contains 181 kinds of active ingredients and thousands identified compounds. Honey is commonly used as a main source of sweet in the diet. However, the use of honey as an alternative natural medicine for many kinds of diseases is recently emerging [13], [14]. Evidence has demonstrated the beneficial effects of honey to reduce the severity of several degenerative diseases. However, the potential of honey as a food supplement to address malnutrition problems in pregnant women is less observed.

Recently, several studies have evaluated the effects of Moringa, honey, or the combination of both as nutrition supplementation in pregnant women. This systematic review aimed to evaluate the potential effects of Moringa, honey, and both compared to ironfolic acid supplements given to pregnant women on the pregnancy outcomes. This review also aims to provide information as recommendation for related future research.

\section{Materials and Methods}

\section{Population, intervention, comparator, and outcomes details}

This review included the studies observed pregnant women in any stage of gestational age. The interventions were Moringa leaves extract, or honey, or the combination of Moringa extract and honey compared to iron-folic acids. Moringa intervention dosage used differentiated over extract or powder. Type of extract is also assessed whether the extract using methanol, ethanol, or water. The duration of intervention is categorized as 2- or 3-months period. The outcomes measured in this review were maternal health status, that is, maternal weight, levels of hemoglobin $(\mathrm{Hb})$, and stress oxidative marker such as malondialdehyde (MDA), 8-hydroxy-2'-deoxyguanosine (8-OHdG), cortisol, and total antioxidant. Measurement at birth includes weight of the placenta and the baby's weight, and baby's length.

\section{Search strategy}

We did a search of articles through PubMed, Scopus, and Google Scholars. Besides, we did search on some of the existing literature in the library of Hasanuddin University, Makassar, Indonesia. We used key terms "pregnancy or pregnant women or antenatal or perinatal" AND "supplements or supplementation or dietary supplementation or dietary supplement" AND "Moringa Oleifera or Honey or Moringa honey" to search in the databases.

Several aspects were observed from each study including initial conditions of pregnant women, age of pregnancy when the intervention started, kind of intervention, dose of intervention, duration of intervention, variable being measured, as well as measurement tools used. The initial conditions of pregnant women are based on the inclusion criteria of the study including anemia, work as informal labor, or exposed to cigarette smoke. Age of pregnancy is distinguished based on first, second, or third trimesters.

\section{Results}

We finally found eight article journal publications and six theses from the library. However, one thesis is refused due to unclear and inconsistent data. We did check for the source of each article and thesis and found that there are only seven studies (Table 1). The first study was conducted in Gowa, a district very closed to Makassar, a capital city of South Sulawesi Province [15, 16]. The second study was conducted in Makassar city, whereas the subjects were pregnant mother worked informally $[17,18]$. The third study was conducted in slum areas of Makassar [19]. The fourth study was conducted in Takalar, another city closed to Makassar, to pregnant women with passive smoker [20], while the fifth study was undertaken in Jeneponto, a district in Southern part from Makassar [21, 22]. Moreover, there are three thesis conducted in subdistrict Tamalatea, Jeneponto District [23], [24], [25] and two thesis carried out in Gorontalo [26], [27]. 
Table 1: Intervention studies on Moringa and honey supplementation on pregnant women

\begin{tabular}{|c|c|c|c|c|}
\hline Study no. & Source of study & Subjects & Study design & Result's summary \\
\hline 1. & $\begin{array}{l}\text { Anang et al. (2014); Ishaq } \\
\text { et al. (2015) }\end{array}$ & $\begin{array}{l}\text { Pregnant mothers, second } \\
\text { trimester, with mild to } \\
\text { moderate anemia. }\end{array}$ & $\begin{array}{l}\text { Mothers divided randomly into two groups; } \\
\text { first received } 800 \mathrm{~g} \text { MOLE plus IFA and } \\
\text { second received IFA for three months. }\end{array}$ & $\begin{array}{l}\text { No differences on 8-OHdG and birth weight between groups. } \\
\text { Hemoglobin and maternal weight increase more in the first } \\
\text { group compared to the second group. }\end{array}$ \\
\hline 2. & $\begin{array}{l}\text { Muis et al. (2014); } \\
\text { Hermansyah et al. (2014) }\end{array}$ & $\begin{array}{l}\text { Pregnant mothers, second } \\
\text { trimester, who worked } \\
\text { informally outside home. }\end{array}$ & $\begin{array}{l}\text { Mothers divided randomly into two groups; } \\
\text { first received } 2000 \mathrm{~g} \text { MOLE plus IFA and } \\
\text { second received IFA for three months. }\end{array}$ & $\begin{array}{l}\text { Maternal weight increased more in the first group, stress, } \\
\text { and } 8-O H d G \text { reduced more in the first group, but hemoglobin } \\
\text { increased in the second group and did not change in the first } \\
\text { group. }\end{array}$ \\
\hline 3. & Nadimin et al. (2015) & $\begin{array}{l}\text { Pregnant mothers, second } \\
\text { trimester, non-anemia. }\end{array}$ & $\begin{array}{l}\text { Mothers divided randomly into two groups; } \\
\text { first received } 2000 \mathrm{~g} \text { MOLE and second } \\
\text { received IFA for } 3 \text { months. }\end{array}$ & $\begin{array}{l}\text { Hemoglobin increased significantly in both groups but MDA } \\
\text { and } 8-O H d G \text { reduced more in the first group. Birth weight was } \\
\text { higher in the first group, but the difference is not significant. }\end{array}$ \\
\hline 4. & Khuzaimah et al. (2015) & $\begin{array}{l}\text { Pregnant mothers, second } \\
\text { trimester, who passive- } \\
\text { smokers, non-anemia. }\end{array}$ & $\begin{array}{l}\text { Mothers divided randomly into two groups; } \\
\text { first received } 2000 \mathrm{~g} \text { Honey, MOLE plus IFA } \\
\text { and second received MOLE and IFA for } 3 \\
\text { months. }\end{array}$ & $\begin{array}{l}\text { Hemoglobin increased significantly in the first group and did } \\
\text { not change in the second group. 8-OHdG reduced more in } \\
\text { the first group. Placenta and birth weight were higher in the } \\
\text { first group. }\end{array}$ \\
\hline 5. & $\begin{array}{l}\text { Nurdin et al. (2018); } \\
\text { Arundhana et al. (2018) }\end{array}$ & $\begin{array}{l}\text { Pregnant mothers, second } \\
\text { trimester, both anemia and } \\
\text { non-anemia. }\end{array}$ & $\begin{array}{l}\text { Mothers divided randomly into three groups; } \\
\text { first received MOLE } 1000 \mathrm{~g} \text {, second } \\
\text { received MOLP } 1000 \mathrm{~g} \text {, and third received } \\
\text { IFA for } 3 \text { months. }\end{array}$ & $\begin{array}{l}\text { Hemoglobin reduced significantly in all groups. Sub-group } \\
\text { analyses in anemic mothers, it increased in the third group } \\
\text { and did not change in other groups. Placenta and birth weight } \\
\text { were higher in the second group compared to the third group. }\end{array}$ \\
\hline 6. & $\begin{array}{l}\text { Yusnidar (2018), Hasni } \\
\text { (2018), and Abdul-Hafid } \\
\text { (2018) }\end{array}$ & $\begin{array}{l}\text { Pregnant mothers, third } \\
\text { trimester with moderate } \\
\text { anemia. }\end{array}$ & $\begin{array}{l}\text { Mothers divided randomly into two groups; } \\
\text { first received } 2000 \mathrm{~g} \text { MOLP and second } \\
\text { received IFA for } 2 \text { months. }\end{array}$ & $\begin{array}{l}\text { Hemoglobin increased in both groups but higher in the first } \\
\text { group. Stress and cortisol reduced significantly in the first } \\
\text { group and did not change in the second group. Birth weight } \\
\text { was higher in the first group. }\end{array}$ \\
\hline 7. & $\begin{array}{l}\text { Ningsih (2018) and Rini } \\
(2018)\end{array}$ & $\begin{array}{l}\text { Pregnant mothers, third } \\
\text { trimester, non-anemia. }\end{array}$ & $\begin{array}{l}\text { Mothers divided randomly into two groups; } \\
\text { first received } 2000 \mathrm{~g} \text { MOLP and second } \\
\text { received IFA for } 2 \text { months. }\end{array}$ & $\begin{array}{l}\text { Stress level and MDA reduced significantly in the first group } \\
\text { and did not change in the second group. Birth weight was } \\
\text { higher in the first group. }\end{array}$ \\
\hline
\end{tabular}

\section{Subject characteristics and research design}

Seven studies found are labeled according to the time of conducted and published (Table 1). In general, pregnant women participated in the study were in the second trimester and received 3 months of intervention. Only study no. 6 and 7 that used the third trimester and received 2 months of intervention. There are three types of initial condition of pregnant women, (1) anemic pregnant women (study numbers 1 and 6), (2) healthy pregnant women (study numbers 3, 4, and 7), and (3) combination between anemic and healthy pregnant women (study numbers 2 and 5). In addition, pregnant women enrolled in study number 2 were those who work informally while in study no. 4 pregnant women who were elected are those who are exposed to cigarette smoke. Regarding the social economy status of participants, almost all studies were done in rural areas and low social economy status.

All studies were randomized, double blind, and controlled design. All studies have two groups, namely, intervention and control, except for one study that used three groups since it compared among group that received Moringa Oleifera leaf extract (MOLE), Moringa Oleifera leaf powder (MOLP), and Iron-folic acid (IFA) (study number 5). In addition, all control groups received IFA, except a study comparing a group that received honey plus MOLE and IFA and a group that received MOLE and IFA (study number 4 ).

This type of intervention can be categorized on Moringa extract and powder. There is one study (study number 1) that used methanol extracts, three studies using ethanol extracts (study numbers 2, 3, and 4) and another study using aqueous extract (study number 5 ). Three studies (study numbers 5,6 , and 7 ) used powder. The duration of intervention is generally 3 months (study number 1-5) while the past two for 2 months (study numbers 6 and 7 ).
The outcomes variables that are used varied on each type of research. All studies measured hemoglobin levels before and after intervention, unless the study conducted in the region of Gorontalo in nonanemic pregnant women (study number 7). Regarding nutritional status of pregnant women, weight, and circumference of the upper arm (MUFA) is only measured in the study numbers 1 and 2 . In addition, the levels of anti-oxidants in the blood of pregnant women were only measured in the study number 3 , while MDA and $8-\mathrm{OHdG}$ were measured in almost of the research, except for the study numbers 5 and 6 . Measurement of birth weight was done in all studies except for study number 2 . Moreover, the salivary cortisol level was only assessed in study number 6 .

\section{Effects of intervention on Moringa and} honey

\section{Increased hemoglobin}

Table 2 shows the effect of the intervention of Moringa and honey on hemoglobin. The group who received a dose of $800 \mathrm{~g}$ MOLE together with IFA showed significantly improved in hemoglobin compared to the group who received only IFA (study number 1). However, the study no. 2 showed that the combination of $2 \mathrm{~g}$ MOLE and IFA did not increase the hemoglobin level. In addition, two studies compared a dose of $2 \mathrm{~g}$ MOLE only and IFA only showed that hemoglobin level increased in both groups (study numbers 3 and 5). However, with the addition of honey (in addition to MOLE and IFA) could increase the hemoglobin level (study number 4). On the other hand, $2 \mathrm{~g}$ of MOLP increased hemoglobin (study number 6). Amount of change in hemoglobin varied among studies. The hemoglobin level increased 92\% with $2 \mathrm{~g}$ of MOLP and increased by $248 \%$ when combined with IFA. 
Table 2: Effects of Moringa and Honey supplementation in pregnant mothers on Hemoglobin

\begin{tabular}{|c|c|c|c|c|c|c|c|}
\hline Study no. & Authors & Groups & Baseline & End line & $p$-value & Change & p-values ( $\%$ change) \\
\hline \multirow[t]{2}{*}{1.} & Ishaq et al. (2015) & MOLE + IFA $(n=33)$ IFA & $11.19 \pm 0.8$ & $11.93 \pm 0.9$ & 0.003 & $0.73 \pm 1.29$ & 0.078 \\
\hline & & $(n=31)$ & $11.50 \pm 0.3$ & $11.70 \pm 0.3$ & 0.268 & $0.21 \pm 1.02$ & $(248 \%)$ \\
\hline \multirow[t]{2}{*}{2} & Muis et al. (2014) & MOLE + IFA $(n=35)$ & $11.8 \pm 0.94$ & $11.77 \pm 1.29$ & 0.909 & $-0.02 \pm 1.32$ & $0.002 \dagger$ \\
\hline & & Iron-folic acid $(n=33)$ & $11.57 \pm 1.20$ & $11.88 \pm 1.50$ & 0.337 & $0.30 \pm 1.80$ & \\
\hline \multirow[t]{2}{*}{3} & Nadimin et al. (2015) & MOLE $(n=35)$ & $11.28 \pm 0.78$ & $11.75 \pm 1.09$ & 0.040 & $0.47 \pm 1.31$ & $0.168 \dagger$ \\
\hline & & IFA $(n=35)$ & $11.28 \pm 0.86$ & $12.27 \pm 1.53$ & 0.003 & $0.99 \pm 1.76$ & $(111 \%)$ \\
\hline \multirow[t]{2}{*}{4} & Khuzaimah et al. (2015) & MOLE + IFA+H $(n=40)$ & $11.88 \pm 1.2312 .68 \pm 1.08$ & $13.52 \pm 1.28$ & 0.020 & $1.64 \pm 1.39$ & $0.001 \dagger$ \\
\hline & & MOLE + IFA $(n=40)$ & & $12.85 \pm 1.33$ & 0.760 & $0.17 \pm 0.74$ & $(865 \%)$ \\
\hline \multirow[t]{2}{*}{5.} & Nurdin et al. (2018) * & MOLE $(n=62)$ & $10.14 \pm 0.629 .98 \pm 0.54$ & $9.98 \pm 1.45$ & 0.418 & $-0.16 \pm 1.540 .11 \pm 1.50$ & $0.028 \dagger$ \\
\hline & & $\operatorname{MOLP}(n=64$ & $10.11 \pm 0.58$ & $10.09 \pm 1.60$ & 0.550 & $0.41 \pm 1.43$ & $(273 \%)$ \\
\hline \multirow[t]{2}{*}{6.} & Yusnidar (2018) & $\operatorname{MOLP}(n=19)$ & $10.22 \pm 0.2110 .20 \pm 0.20$ & $11.68 \pm 0.40$ & 0.216 & $1.46 \pm 0.39$ & 0.001 \\
\hline & & $\operatorname{IFA}(n=19)$ & & $10.95 \pm 0.38$ & 0.433 & $0.76 \pm 0.39$ & $(92 \%)$ \\
\hline
\end{tabular}
showed it higher in group received MOLE+IFA+honey.

Interestingly, the addition of honey led to a nine-fold increment of hemoglobin level.

\section{MUAC)}

\section{Improved nutritional status (weight and}

Only two studies measured and reported nutritional status of pregnant women. Weight and MUAC of pregnant women who received MOLE plus IFA increased better than those who received IFA (study numbers 1 and 2). The increased weight was not associated with the eating patterns in both groups. Study number 2 showed that there was no relationship between the improvements of nutritional status of the mother with their food intake [17].

\section{Increase in antioxidants and reduce MDA and 8-OHdG}

The levels of antioxidants, MDA, and 8-OHdG were measured in most of the study (study numbers 1 , $2,3,4$, and 7 ). One study revealed that the antioxidant levels increased in groups of pregnant women who received Moringa and even declined in those who receive IFA with the similar results are also obtained from the level of MDA and 8-OHdG. Study no. 1 showed that there is no significant difference between the groups that received the Moringa plus IFA and IFA only. However, study numbers $2,3,4$, and 7 found significant differences between groups that received Moringa only or Moringa plus IFA compared to group that received IFA only.

\section{Decline in the level of stress and cortisol}

There are three studies measuring stress (Study numbers 2, 6, and 7). From those three studies, stress level reduced in group received Moringa leaves. Nevertheless, the stress level of pregnant women who received IFA remained high or increased. The measurement of cortisol in saliva has been done in study number 6 , which showed a decline of cortisol in the group of pregnant women who received Moringa. On the other hand, a group received IFA showed cortisol levels even increased (data are not shown).

\section{weight \\ Increased weight of placenta and birth}

All studies measured birth weight except the study number 2 (Table 3 ). However, only two studies measured weight of placenta (study numbers 4 and 5 ). From these studies, pregnant women received honey and Moring a plus IFA have babies with a higher placental weight and birth weight compared to those received Moringa plus IFA. Similarly, study in Jeneponto [22], the weight of placenta as well as birth weight were higher in group receiving MOLP compared to other groups.

The differences of birth weight between the intervention groups were found in six studies. It turns out to be higher in Jeneponto (no. 6) in groups of anemic pregnant women received 2-g dose of MOLP over 2 months period $(453 \mathrm{~g})$, followed by a group of nonanemic pregnant women received $2 \mathrm{~g}$ of MOLP over 2 months period $(232 \mathrm{~g})$. Both of these studies were done on the third trimester of pregnancy. Furthermore, the large differences found in the group of pregnant women being given honey and Moringa plus IFA in study no. 4 $(210 \mathrm{~g})$ and on pregnant women given Moringa powder on the second trimester in study no. $5(139 \mathrm{~g})$.

\section{Discussion}

This systematic review shows that supplementation Moringa leaves or honey can be given to pregnant women and provides benefits on health of mother and baby. Some studies have shown that Moringa leaves supplementation significantly elevated levels of hemoglobin, which lead to a lower prevalence of anemia, raising the weight of the mother, lowering stress and cortisol levels, and raise the levels of antioxidants in the blood. In addition, some research shows an increase in the placenta and birth weight of the baby.

Some research demonstrated that giving Moringa on pregnant women can improve the nutritional status in the form of increased weight and MUAC. The improved nutritional status can be attributed to improved maternal consumption patterns and reduction of stress. 
Table 3: Effects of Moringa and Honey supplementation in pregnant mothers on placenta and birth weight

\begin{tabular}{|c|c|c|c|c|c|c|}
\hline Study no. & Authors & Groups & Placenta weight (g) & p-values (differences) & Birth weight (g) & p-values (differences) \\
\hline \multirow[t]{2}{*}{1.} & Ishaq et al. (2015) & MOLE + IFA $(n=33)$ & - & - & $3070 \pm 370$ & 0.650 \\
\hline & & $\operatorname{IFA}(n=31)$ & & & $3030 \pm 430$ & $(40 \mathrm{~g})$ \\
\hline \multirow[t]{2}{*}{3.} & Nadimin et al. (2015) & MOLE $(n=35)$ & - & - & $3105 \pm 520$ & 0.365 \\
\hline & & IFA $(n=35)$ & & & $3022 \pm 530$ & $(83 \mathrm{~g})$ \\
\hline \multirow[t]{2}{*}{4.} & Khuzaimah et al. (2015) & MOLE + IFA+H $(n=40)$ & $522 \pm 138$ & 0.21 & $3235 \pm 385$ & 0.020 \\
\hline & & MOLE + IFA $(n=40)$ & $492 \pm 70$ & $(30 \mathrm{~g})$ & $3025 \pm 368$ & $(210 \mathrm{~g})$ \\
\hline \multirow[t]{3}{*}{5.} & Arundhana et al. (2018) & MOLE $(n=146)$ & $531 \pm 159$ & 0.001 & $3162 \pm 528$ & 0.033 \\
\hline & & $\operatorname{MOLP}(n=155)$ & $567 \pm 141$ & $(64 \mathrm{~g})$ * & $3240 \pm 454$ & $(139 \mathrm{~g})$ * \\
\hline & & IFA (n 152) & $503 \pm 153$ & & $3101 \pm 412$ & \\
\hline \multirow[t]{2}{*}{6.} & Abdul-Hafid (2018) & $\operatorname{MOLP}(n=19)$ & - & - & $3390 \pm 383$ & 0.001 \\
\hline & & IFA $(n=19)$ & & & $2937 \pm 400$ & $(453 \mathrm{~g})$ \\
\hline \multirow[t]{2}{*}{7.} & Ningsih (2018) & $\operatorname{MOLP}(n=20)$ & - & - & $3147 \pm 197$ & 0.002 \\
\hline & & IFA $(n=20)$ & & & $2915 \pm 237$ & $(232 \mathrm{~g})$ \\
\hline
\end{tabular}

Reduction of stress levels will give a better feeling and it will provide comfort, peace, and happiness [4].

Moringa supplementation on pregnant women can increase the levels of hemoglobin and decrease the incidence of anemia in pregnant women. Effect on increasing hemoglobin can be connected with the content of iron and a variety of vitamins and minerals contained in the Moringa leaves [28]. The levels of iron in MOLP are 25 times higher than the levels of iron in the spinach. Moreover, Vitamin A in MOLP is 10 times higher than carrots [29]. Other nutrients such as potassium, calcium, and amino acids are also found significantly higher in Moringa leaves than other plant leaves. The bioactive compounds in the Moringa leave allow an elevated iron content in the body better than usage of iron. In addition, numerous antioxidants in Moringa leave can also give impact on the permeability of iron in the body. It has been demonstrated in one study that the bioavailability of iron on Moringa leave is much better compared to iron from a commercial supplement [30].

Moringa influence in lowering stress and cortisol levels has also been found in several studies in this review. This supports previous research that has been done in various places [31], [32]. Moringa contains antioxidants and various enzymes that can perform a reduction in the levels of free radicals. In the course of pregnancy, an expectant mother will undergo a continuing rise in the level of free radicals. In certain circumstances, the level of free radicals in pregnant women could cause the occurrence of various disorders such as increased blood pressure, a range of disorders that can be experienced by a pregnant mother is pre-eclampsia, abortion, stillbirth, bleeding, premature, and maternal death [33]. Perinatal mortality is also influenced by the effects of free radicals since in the womb [34]. The antioxidant content as well as various other bioactive compounds in Moringa leaves can overcome these disorders/problems/adverse impacts.

Moringa may increase the weight of the placenta and birth weight. Birth weight under $2,500 \mathrm{~g}$ is considered low birth weight (LBW). From all studies reviewed, none of the babies born in the group that received the Moringa experienced LBW. Although not a significant difference occurred in some of the research, that the group that received the Moringa always seemed heavier than that received the IFA. There are three mechanisms that can explain this finding. First, the increase iron in those who received Moringa supplements. The previous studies had shown that the intervention of iron-folic acid may increase birth weight through the improvement of the relationship of mother and fetus in the uterus. In the uterus, the mother provides essential nutrients for the fetus to develop [35]. Second, Moringa's protection from the incident of stress and in the increased cortisol levels cause growth and development of infant becomes optimal. Third, improving the nutritional status of pregnant women indirectly will provide more food for the fetus. However, further studies with a better design are required to support this mechanism.

Research has been done using different dosages of Moringa leave. The minimum use was one capsule with a dose of $800 \mathrm{mg}$ and the highest dose was 4 capsules where one capsule contains $500 \mathrm{mg}$ of total $2000 \mathrm{mg}$. In addition, the Moringa leaves formulation could be from extract or powder. The results of laboratory examination have shown that the content of the extract and powder is somewhat different; however, all nutrients and phytochemicals were found in both forms [9]. Compared to the extraction forms, the powder form is cheaper and more affordable for the community. This review has also shown that MOLP with the doses of $2 \mathrm{~g} /$ day in pregnant women has better impact. However, some babies reach a birth weight of up to $4,000 \mathrm{~g}$. It will be a problem during delivery, especially for those who do not do regular checks to the midwife. Moringa supplementation should be stopped where there is an indication of heavy birth weight. A future study is suggested to conduct to find a more precise dose considering the condition of the health of pregnant women especially pre-pregnant weight.

This review only found one study that gives honey supplementation to pregnant women. In the study, honey is given to pregnant women who are exposed to cigarette smoke (passive smokers). Honey is combined with MOLE and IFA. This study showed a better protection of gene damage in mothers who obtained honey, MOLE plus IFA compared to a group receiving MOLE plus IFA. In addition, the weight of placenta and birth weight was higher on the obtain 
honey, MOLE plus IFA. However, a future study needs to be done to compare a group of pregnant women who received honey alone, Moringa alone, or both honey and Moringa in adequate doses.

\section{Conclusion}

We conclude that the supplementation of natural foods, Moringa and honey, to expectant mothers may improve maternal and baby health. Both MOLE and MOLP are associated with in the increased of hemoglobin, birth weight, and also prevent cellular damage. In addition, a dose $2000 \mathrm{mg}$ of MOLP may have better impact. Further research which combines two natural products (Moringa and honey) for expectant mothers is required to investigate the synergism effects.

\section{Acknowledgment}

We thank to Hesti Arini in helping to read through this article and correcting the language and Nurzakiah Hasan who providing some information in finishing this article.

\section{References}

1. Black RE, Allen LH, Bhutta ZA, Caulfield LE, de Onis $M$, Ezzati $\mathrm{M}$, et al. Maternal and child undernutrition: Global and regional exposures and health consequences. Lancet. 2008;371(9608):243-60. https://doi.org/10.1016/ s0140-6736(07)61690-0

PMid:18207566

2. Sloan NL, Lederman SA, Leighton J, Himes JH, Rush D. The effect of prenatal dietary protein intake on birth weight. Nutr Res. 2001;21(1):129-39. https://doi.org/10.1016/ s0271-5317(00)00258-x

3. dos Santos Q, Sichieri R, Marchioni DM, Junior EV. Brazilian pregnant and lactating women do not change their food intake to meet nutritional goals. BMC Pregnancy Childbirth. 2014;14(1):186. https://doi.org/10.1186/1471-2393-14-186 PMid:24890188

4. Lindsay KL, Buss C, Wadhwa PD, Entringer S. The interplay between nutrition and stress in pregnancy: Implications for fetal programming of brain development. Biol Psychiatry. 2019;85(2):135-49. https://doi.org/10.1016/j. biopsych.2018.06.021 PMid:30057177

5. Entringer S, Buss C, Wadhwa PD. Prenatal stress, development, health and disease risk: A psychobiological perspective-2015 curt richter award paper. Psychoneuroendocrinology. 2015;62:36675. https://doi.org/10.1016/j.psyneuen.2015.08.019 PMid:26372770
6. Walker J, Littlewood R. Pragmatic implementation studies to improve nutrition practices and policies: Childcare during the first 1000 days as a contributor to long-term health. Public Health Nutr. 2018;21(7):1209-11. https://doi.org/10.1017/ s1368980018000022

PMid:29642971

7. Sampeangin H, Thaha AR, Hadju V, Sirajuddin S, Malongi A Effectiveness of PMT supplement biscuit to hemoglobin content of pregnant woman in Parepare city. Int J Sci Basic Appl Res. 2017;36(6):156-64

8. Haider BA, Yakoob MY, Bhutta ZA. Effect of multiple micronutrient supplementation during pregnancy on maternal and birth outcomes. BMC Public Health. 2011;11 Suppl 3:S19. https://doi.org/10.1186/1471-2458-11-s3-s19

PMid:21501436

9. Vongsak B, Sithisarn P, Mangmool S, Thongpraditchote S, Wongkrajang Y, Gritsanapan W. Maximizing total phenolics, total flavonoids contents and antioxidant activity of Moringa oleifera leaf extract by the appropriate extraction method. Ind Crops Prod. 2013;44:566-71. https://doi.org/10.1016/j. indcrop.2012.09.021

10. Leone A, Spada A, Battezzati A, Schiraldi A, Aristil J, Bertoli S. Cultivation, genetic, ethnopharmacology, phytochemistry and pharmacology of Moringa oleifera Leaves: An overview. Int J Mol Sci. 2015;16(6):12791-835. https://doi.org/10.3390/ ijms160612791

11. Pasupuleti VR, Sammugam L, Ramesh N, Gan SH. Honey, propolis, and royal jelly: A comprehensive review of their biological actions and health benefits. Oxid Med Cell Longev. 2017;2017:1259510. https://doi.org/10.1155/2017/1259510 PMid:28814983

12. Islam MR, Pervin $T$, Hossain $H$, Saha B, Hossain SJ Physicochemical and antioxidant properties of honeys from the sundarbans mangrove forest of Bangladesh. Prev Nutr Food Sci. 2017;22(4):335-44. https://doi.org/10.3746/pnf.2017.22.4.335 PMid:29333387

13. Choi JY. Complementary therapy for improvement of quality of life in cancer patients. J Korean Med Assoc. 2008;51(5):435-48.

14. Alam F, Islam MA, Gan SH, Khalil MI. Honey: A potentia therapeutic agent for managing diabetic wounds. Evid Based Complement Alternat Med. 2014;2014:169130.

PMid:25386217

15. Otoluwa A, Salam A, Syauki $Y$, Nurhasan $M$, Monoarfa $Y$, As'ad S, et al. Effect of Moringa oleifera Leaf extracts supplementation in preventing maternal DNA damage. Int J Sci Res Publ. 2014;4(11):1-4.

16. Iskandar I, Hadju V, As'ad S, Natsir R. Effect of Moringa Oleifera Leaf extracts supplementation in preventing maternal anemia and low birth weight. Int J Sci Res Publ. 2015;5(2):1-3.

17. Muis M, Hadju V, Russeng S, Naiem MF. Effect of Moringa Leaves extract on occupational stress and nutritional status of pregnant women informal sector workers. Int J Curr Res Acad Rev. 2014;2(11):86-92

18. Hermansyah H, Hadju V, Bahar B. Moringa Leaves extract on food intake and weight gain of pregnant women working in informal sector. J IImu Kesehatan Masyarakat. 2014;5(3):192-201.

19. Nadimin, Hadju V, As'ad S, Buchari A. The extract of Moringa Leaf has an equivalent effect to iron folic acid in increasing hemoglobin levels of pregnant women: A randomized control study in the coastal area of Makassar. Int J Sci Basic Appl Res. 2015;22(1):287-94. https://doi. org/10.5958/0976-5506.2019.00102.5

20. Khuzaimah A, Hadju V, As'ad S, Abdullah N, Burhanuddin B, Riu D. Effect of honey and Moringa oleifera Leaf extracts supplementation for preventing DNA damage in passive smoking pregranancy. Int J Sci Basic Appl Res. 2015;23(1):138-45. 
21. Nurdin MS, Hadju V, Zulkifli A, Arundhana Al. The effect of Moringa Leaf extract and powder to haemoglobin concentration among pregnant women in Jeneponto regency. Indian J Public Health Res Dev. 2018;9(2):262-7. https://doi. org/10.5958/0976-5506.2018.00130.4

22. Arundhana AI, Nurdin MS, Hadju V, Ansariadi A, Zulkifli AJ. The effect of Moringa-based supplementation on fetal birth weight in Jeneponto regency. J Pharm Nutr Sci. 2018;8(3):144-9. https:// doi.org/10.6000/1927-5951.2018.08.03.9

23. Hafid RA. Effect of Moringa oleifera Leaf Powder in Pregnant Women on Brith Weight. Makassar: Midwifery Program, Hasanuddin University; 2018.

24. Hasni. The Effect of Moringa oleifera Leaf Powder in Pregnant Women on Stress and Salivary Cortisol Level. Makassar: Midwifery Program, Hasanuddin University; 2018.

25. Yusnidar. The Effect of Moringa oleifera Leaf Powder in Pregnant Women on Hemoglobin. Makassar: Midwifery Program, Hasanuddin University; 2018.

26. Ningsih S. The Effect of Moringa oleifera Leaf Powder Supplementation in Pregnant Women on Maternal Stress and Birthweight. Makassar: Midwife Program, Hasanuddin University; 2018.

27. Rini AS. The Effect of Moringa oleifera Leaf Powder in Pregnant Women On Maternal Malondialdehyde and Brith Weight. Makassar: Midwifery Program, Hasanuddin University; 2018.

28. Valdez-Solana MA, Mejía-García VY, Téllez-Valencia A, García-Arenas G, Salas-Pacheco J, Alba-Romero JJ, et al. Nutritional content and elemental and phytochemical analyses of grown in Moringa oleifera Mexico. J Chem. 2015;2015:860381. https://doi.org/10.1155/2015/860381

29. Gopalakhrisnan L, Doriya K, Kumar DS. Moringa oleifera: A review on nutritive importance and its medicinal application. Food Sci Hum Wellness. 2016;5(2):49-56. https://doi. org/10.1016/j.fshw.2016.04.001
30. Saini RK, Manoj P, Shetty NP, Srinivasan K, Giridhar P. Dietary iron supplements and Moringa oleifera Leaves influence the liver hepcidin messenger RNA expression and biochemical indices of iron status in rats. Nutr Res. 2014;34(7):630-8. https:// doi.org/10.1016/j.nutres.2014.07.003

\section{PMid:25150122}

31. Stewart CP, Oaks BM, Laugero KD, Ashorn U, Harjunmaa U, Kumwenda $\mathrm{C}$, et al. Maternal cortisol and stress are associated with birth outcomes, but are not affected by lipidbased nutrient supplements during pregnancy: An analysis of data from a randomized controlled trial in rural Malawi. BMC Pregnancy Childbirth. 2015;15(1):346. https://doi.org/10.1186/ s12884-015-0793-8 PMid:26694646

32. Lindsay KL, Buss C, Wadhwa PD, Entringer S. The interplay between maternal nutrition and stress during pregnancy: Issues and considerations. Ann Nutr Metab. 2017;70(3):191-200. https://doi.org/10.1159/000457136 PMid:28301838

33. Weinstock M. The potential influence of maternal stress hormones on development and mental health of the offspring. Brain Behav Immun. 2005;19(4):296-308. https://doi. org/10.1016/j.bbi.2004.09.006 PMid: 15944068

34. Mulder EJ, Robles de Medina PG, HuizinkAC, van den Bergh BR, Buitelaar JK, Visser GH. Prenatal maternal stress: Effects on pregnancy and the (unborn) child. Early Hum Dev. 2002;70(12):3-14. https://doi.org/10.1016/s0378-3782(02)00075-0 PMid: 12441200

35. Rasmussen KM, Stoltzfus RJ. New evidence that iron supplementation during pregnancy improves birth weight: New scientific questions. Am J Clin Nutr. 2003;78(4):673-4. https:// doi.org/10.1093/ajcn/78.4.673

PMid:14522723 